\title{
The acquisition of the Hungarian definite conjugation by learners of different first languages
}

\author{
PÉTER DURST \\ University of Szeged, University of Zagreb \\ BOGLÁRKA JANURIK \\ University of Szeged
}

\begin{abstract}
This paper aims to examine whether the fact that both the Hungarian and the Erzya-Mordvin languages distinguish between definite and indefinite verb conjugation facilitates acquisition. Data was collected a) from a group of 83 language learners of various L1s and b) from 11 learners whose L1 is the Erzya-Mordvin language, using a questionnaire containing 210 test questions. Contrastive analysis of the Hungarian and the Mordvin definite object complexes reveals several differences between the two systems which make it difficult for learners to rely on analogies when deciding on the type of conjugation. Our results suggest that the time spent in the target language environment helps learners acquire the use of the definite conjugation, especially in the most difficult cases where an implicit object is implied by the context.
\end{abstract}

Keywords: second language acquisition; L1 influence; agreement; definite objects; target language environment; Mordvin; Hungarian 


\section{Introduction}

Several types of grammatical agreement exist in Hungarian, one of which is very rare among the world's languages and thus presents special difficulties for learners of Hungarian as a foreign language. In Hungarian the definite object is marked on the verbs. Thus depending on the definiteness of the object, we distinguish between a definite (a.k.a. "objectconjugation") and an indefinite ("subject-conjugation") paradigm in all tenses and moods, including the present, the past, the imperative and the conditional. This paper examines the acquisition of the Hungarian definite and indefinite conjugation by two groups of learners. The first group consisted of learners of various L1s (Group 1) while in the second group all respondents' L1 was the Erzya-Mordvin language (Group 2). Given that the definite object is marked on the verbs both in Hungarian and in the Erzya-Mordvin language, we set out to examine whether this common feature helps the Erzya-Mordvin learners in the acquisition of the Hungarian definite conjugation. To carry out such an analysis, it is crucial to have at least a general idea about the conjugation system of the Hungarian and the Erzya-Mordvin languages. Therefore the presentation of the research data shall be preceded by a comparative summary of the definite conjugation in these two languages. The comparative description was prepared by Boglárka Janurik, who also organized the testing of the Erzya-Mordvin students. Péter Durst is responsible for the rest of the project, including the general planning and the evaluation of the test.

The research is based on a questionnaire consisting of a total of 446 test questions. The questionnaire had two main parts which contained 236 and 210 test questions respectively. Verb conjugation was examined in the second part, where learners were asked to write the correct form of the verb given in brackets. The first group of 83 learners completed both parts of the questionnaire, while the Erzya-Mordvin students filled in only the second part, which examined verb conjugation. 


\section{Theoretical background to the definite conjugation (typological and contrastive aspects)}

In this section, a contrastive analysis is provided of the definite conjugation in the Hungarian and Mordvin languages. The first subsection (2.1.) introduces the main characteristics and classification types of conjugations that are object-dependent, i.e. the finite verb form is marked (usually in a specific form) if the sentence contains an object.The typological overview is based on Havas (2005).

In the following subsections, brief descriptions of the Hungarian and the Mordvin systems are provided (in 2.2. and 2.3., respectively). Finally, subsection 2.4. presents the similarities and differences of the two languages as regards their type and use of the objective conjugation.

\subsection{Typological overview of the definite conjugation}

Contrastive linguistics is usually defined as a "subdiscipline of linguistics which is concerned with the comparison of two or more languages (or subsystems of languages) in order to determine both the differences and similarities that hold between them" (Fisiak 1981: 1).

Mordvin and Hungarian have been studied contrastively to a great extent, especially as regards their objective conjugation, since the Mordvin languages (Moksha and Erzya) are the only languages in the Finno-Permic branch of the Finno-Ugric language family that have two separate conjugations, one of which has markers (in this case suffixes) relating to the object.

Debates in the literature concern both terminological questions and origins of the objective conjugation.

Theories pertaining to the origins of the objective / definite conjugation in the Uralic languages are not discussed here. The approach taken in this paper is contrastive rather than historical-linguistic. Thus similarities between this feature of the Hungarian and the Mordvin languages are explained by their association with general tendencies, rather 
than by common origins of the objective / definite conjugation in one of the proto-language stages. According to Havas (2005), there are general typological explanations for the facts that the paradigms of the objective / definite conjugations are the most complex in the third person, and that the verbal suffixes which developed from agglutinated personal pronouns are present in the objective / definite conjugation type (and not in the subjective / indefinite one).

Terminologically speaking, subjective-objective and indefinitedefinite are the most common pairs of terms in the literature about both Hungarian and Mordvin. Interestingly enough, although the Hungarian equivalents of the subjective-objective opposition (alanyi and tárgyas) are widely applied in the Hungarian-language literature, the terms indefinite-definite are used in the English-language articles and grammar books on both Hungarian and Mordvin. In this paper, the term definite conjugation is applied because it is the definiteness of the object that determines the use of this conjugation in Hungarian. ${ }^{1}$ In Mordvin, the choice of conjugation depends on a group of different factors (see below).

Although the pair of terms indefinite-definite might be ambiguous in a number of cases, given that the definiteness of the object is only one of the numerous criteria which determine the use of this conjugation type, we apply the terms indefinite and definite conjugations consistently throughout this paper. Indeed, the terms subjective and objective conjugation would be even more misleading, as there are cases in both languages where, despite the presence of an object, the verb is in the non-marked subjective / indefinite form. The definiteness of the object is a common criterion that determines the use of the definite conjugation in the languages under study. We use these terms in view of the way it simplifies the complex phenomenon of the choice between the two basic conjugation types in these languages.

\footnotetext{
1 Except for the special -lak/-lek forms which are used in case of a first person singular subject and second person singular or plural object. In this case, the decisive factor is the person of the object and the subject, and not the definiteness of the object.
} 
Another pertinent factor is the fact that Mordvin and Hungarian represent unique cases in the Uralic language family, as they both have grammaticalized definite-marking forms of nouns. In Hungarian, analytic forms are used (definite articles), while Mordvin languages apply synthetic forms (definite declension suffixes). In this paper, wherever the terms indefinite and definite are used for both declension and conjugation types, we have striven to eliminate such ambiguity.

In the following, a typological classification of languages having some form of an "object-dependent" conjugation is presented, based on Havas (2005) .

According to Havas (2005: 148), there are two criteria for an objective conjugation: the language must have finite verbs and a distinct morphological marker (or a special form of the verb) which indicates that there is a type of agreement between the predicate and the object.

The choice between the conjugation types depends on the object in these languages. This "object-dependency" can be either extensive or intensive. In the extensive type, the decisive factor is the transitivity of the verb: the subjective conjugation is used with intransitive verbs, while the objective conjugation is present in the case of transitive verbs. The traditional subjective-objective differentiation used in Hungarian grammars would be applicable to this type of the object-dependent conjugations.

In languages showing intensive "object-dependency", the choice of the marked conjugation type depends on a special characteristic of the object. This intensive object-dependency is found both in Hungarian and the Mordvin languages. Intensive object-dependency is also present in the Samoyedic and Ob-Ugric languages, but the characteristics of these systems are not discussed in this paper.

In the following sections, criteria determining the choice of the definite conjugation are presented, first for Hungarian and Mordvin separately; an overview is then given of the similarities and differences of the two systems. 


\subsection{Hungarian}

In Hungarian there are three conjugation types (Balásné 1999), two of which are "object-dependent", i.e. their use is required by certain object types. The choice between the conjugation types is determined by whether or not there is an object argument of the predicate and whether this object is definite. In case of a definite third-person object, the definite conjugation is applied. In other cases, the indefinite conjugation is used. The third conjugation type (with the suffixes -lak/-lek) is applied if the subject is first person singular while the object is in the second person (both with singular and plural forms). The status of the -lak/-lek forms in relation to the indefinite / definite distinction has been highly debated. In this paper, the focus is on the so-called definite conjugation, i.e. verbs with a definite third-person object; the -lak/-lek forms are not discussed further.

The three criteria for the use of definite conjugation in the Hungarian language are the following (Balásné 1999: 382):

1) there is an object argument of the predicate,

2) the object is in the third person,

3) the object is definite.

An object is considered to be definite in Hungarian if it has a determiner (definite article, demonstrative pronoun) and/or a possessive suffix; if it is a proper noun, a pronoun of a certain type (demonstrative, thirdperson personal, reciprocal or reflexive), an ordinal or a (non)-finite clause.

In the section that follows (2.3.), the more complex Mordvin definite conjugation will be presented. Finally the two systems will be contrasted. 


\subsection{Mordvin}

Among the Uralic languages, the most complex form of the definite conjugation can be found in the Mordvin languages, where the verbal forms indicate the number and the person of the definite object. Raun (1988: 105) mentions that there could be 112 different forms if there were a separate suffix referring to all persons and numbers for all subject-object pairs. Nevertheless, we can find a full paradigm only in the third person, thus enabling differentiation between 61 separate allomorphs. Trosterud points out that the "only distinction that never is blurred via homonymy, is the object person" (2006: 298). However, we can find widespread homonymy in the paradigms as regards subject person.

Since the focus of this paper is the use of the definite conjugation, the paradigms of both languages are not discussed in detail.

In the Mordvin languages, there are three criteria to be fulfilled in the case of definite conjugation: there is a definite object in the sentence, the verb is transitive and the action is perfective (Zaicz 2004: 212). The last criterion can be illustrated with the following examples:

(1) ved'-eńt' kand-i-ń

water-DEF.GEN bring-PST-SG1

'I brought water in'

(2) ved'eńt' kand-i-ja

water-DEF.GEN bring-PST-SG $3<$ SG 1

'I brought the water in'

In (1), the action is imperfective and the conjugation is indefinite, while in (2), the action is perfective and the verb is in the definite conjugation. Yet both sentences have a definite-marked object vedent ' 'the water' (ved' 'water', -en't' an allomorph of the definite marker)2 (Keresztes 1999).

The main criteria are summarized by Patayné (1983:139) in figure 1 (Zaicz 2003: 168).

2 In contemporary Mordvin, the genitive is the case used for case-marking the object; historically this goes back to a separate accusative case. 


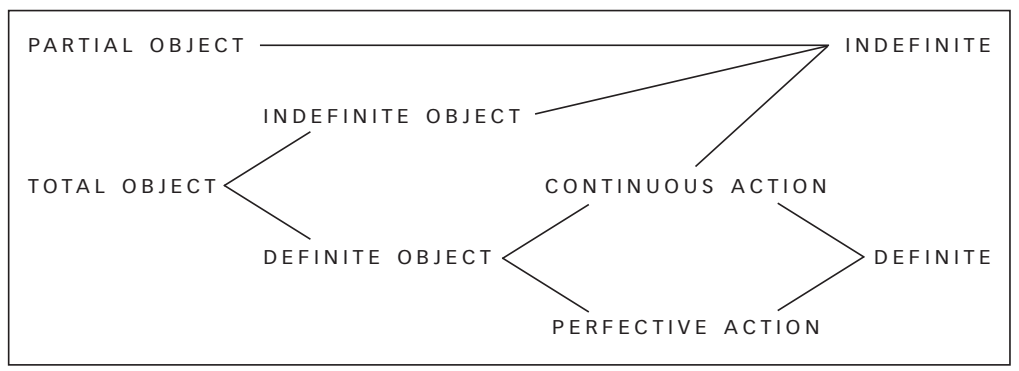

FIGURE 1. Criteria for definite conjugation (Zaicz 2003: 168)

In figure 1, the terms indefinite and definite refer to the indefinite and definite conjugations, respectively. If the argument of the verb is a partial object, the indefinite conjugation is used. In the case of a total object, other criteria also have to be taken into consideration. If the total object is in the indefinite declension, the verb is used with the indefinite conjugation form. If the total object is definite, the use of the conjugation types depends on the perfectiveness of the action.

Partial objects occur with special verbs jarsams 'eating', simems 'drinking'. In these cases, the verb is in the indefinite conjugation and the argument is in the ablative case (examples are from Zaicz 2003, with modifications):

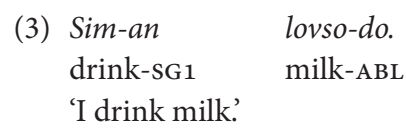

Total objects can be indefinite and definite. In case of an indefinite object, the verb is in the indefinite conjugation and the object is in the nominative case:

(4) Son rama-ś lišme.

(s)he buy-pst horse

'(S)he bought a horse.' 
In Erzya, the object can be considered definite in the following cases:

1) if it is in definite declension (in the glossing the first element after the verb stem indicates the person and the number of the object, while the second one shows the person and number of the subject):
(5) Ne-sa
pando-ńt
see-SG3<SG1 mountain-DEF.GEN
'I see the mountain.'

2) if it is in the possessive declension (i.e. carries a possessive suffix):
(6) Učo-sịnek
teta-nok-
ava-nok.
wait-PST.PL3 $<$ PL1 father-POSS.PL1 mother-POSS.PL1
'We waited for our parents.'

3) if it is semantically definite (a personal name or personal pronoun):
(7) Učo-sa
Peta-ń.
wait-SG3<SG1 Pete-GeN
'I wait for Peter'.

However, the presence of a definite object does not unambiguously trigger the use of the definite conjugation. If the aspect of the action is progressive, the indefinite form of the verb is used. Compare the following examples in which the first sentence has continuous meaning, while the second one is its perfective equivalent. (The object is definite in both cases.)
(8a) Śrmad-an
śorma-ńt'.
write-SG1 letter-DEF.GEN
'I am writing the letter.'
(8b)Śrmad-sa śorma-ńt. write-SG3<SG1 letter-DEF.GEN 'I write the letter.'


There are several exceptions to this rule. With verbs such as ńejems 'see' or večkems 'love', it is the definite form of the object that is used, although the aspect of the action is progressive.

On the basis of Zaicz (2003) and Balásné (1999), an overview shall now be given of the cases in which definite conjugation is used in the Mordvin languages. Subsequently, the use of the definite conjugation in Hungarian and the Mordvin languages shall be compared on the basis of the form of the object.

In language use there are great differences between the two Mordvin languages; for example Moksha uses the definite conjugation more extensively than Erzya (Alhoniemi 1996: 69), a difference that can be observed particularly in present tense forms. Moreover, there are internal variations within the languages, between the standard and the dialects. The standard variety of Erzya resembles Moksha, while the dialects are characterized rather by the dominance of the indefinite conjugation (even in the case of nominals with possessive suffixes and the pronouns, cf. below). In standard texts of contemporary Moksha, 23\% of the verbal forms are in definite conjugation, while in the case of Erzya, this number only attains to $9 \%$ (Alhoniemi 1996: 69).

\subsection{Differences and similarities between the two systems}

This section compares the uses of the definite and indefinite conjugation in Hungarian and Mordvin. Table 1 mainly represents data from the standard languages, but also includes the dialects, especially in cases where the conjugation type used in the dialect differs from the one used in the standard variety.

The emphasis is on the object types which trigger different conjugation types in Hungarian and the Mordvin languages, as these are possible sources of L2 errors. The overview is based on Zaicz (2003: 170-175) and Balásné (1999). 
TABLE 1. Differences and similarities between Hungarian and Mordvin

(D: definite conjugation, I: indefinite conjugation, I/D: both definite and indefinite conjugations are possible; H: Hungarian, M: Mordvin)

\begin{tabular}{|c|c|c|}
\hline The object is... & Hungarian & Mordvin \\
\hline a noun carrying a possessive suffix & $\mathrm{D}$ & $\mathrm{D}$ (I: dialects) \\
\hline a proper noun & $\mathrm{D}$ & $\mathrm{D}$ (I: dialects) \\
\hline a 3rd-person personal pronoun & $\mathrm{D}$ & $\mathrm{D}$ (I: dialects) \\
\hline a 3rd-person reflexive pronoun & $\mathrm{D}$ & $\mathrm{I} / \mathrm{D}$ \\
\hline a 3rd-person reciprocal pronoun & $\mathrm{D}$ & $\mathrm{I} / \mathrm{D}$ \\
\hline a demonstrative pronoun & $\mathrm{D}$ & $\mathrm{I} / \mathrm{D}$ \\
\hline a pronoun meaning 'each of them' & $\mathrm{D}$ & D (I: rare) \\
\hline $\begin{array}{l}\text { a noun with a demonstrative pronoun } \\
\text { modifier or with overt definiteness } \\
\text { marking }(\mathrm{H} \text { : definite article, } \mathrm{M} \text { : definite } \\
\text { declension) }\end{array}$ & $\mathrm{D}$ & $\mathrm{D}$ (I: dialect) \\
\hline a non-finite subordinate clause & $\mathrm{D}$ & I \\
\hline a finite subordinate clause & $\mathrm{D}$ & I (D: rare) \\
\hline a 1 st- or 2nd-person object & $\mathrm{I}^{3}$ & $\mathrm{D}$ \\
\hline a case-inflected relative pronoun & I & $\mathrm{D}$ \\
\hline $\begin{array}{l}\text { a case-inflected indefinite pronoun } \\
\text { (except for the one meaning 'all of them', } \\
\text { see above) }\end{array}$ & I & $\mathrm{D}$ \\
\hline
\end{tabular}

The status of the -lak/-lek ( $\mathrm{sG} 2<\mathrm{sG} 1)$ form in relation to the indefinite / definite distinction is not discussed here. 
As regards the standard languages, differences between Hungarian and (Erzya)-Mordvin can be found only in the case of (some types of) pronouns, subordinate clauses and first- and second-person objects. However, if we also include the dialects, there are more discrepancies.

In the majority of the cases, especially if the object is in the third-person, the use of the definite conjugation overlaps in the given languages.

In a contrastive analysis, we have to take into consideration instances in which one of the languages lacks an equivalent for a (morphological) category present in the other. For example, there are no equivalents in Mordvin for all of the Hungarian pronouns with the suffix -ik (e.g. amelyik [relative pronoun] 'which') which trigger the definite conjugation in Hungarian. However, if there is an equivalent, as in the case of the Erzya pronoun kona 'which', corresponding to Hungarian melyik 'which (of them)?', the definite conjugation is applied in both languages.

A special use of the definite conjugation in both Hungarian and the Mordvin languages concerns cases in which the object pronouns are dropped, i.e. the zero form stands for the "original" definite object (Mészáros 2000: 87).

The most striking differences are detectable if the object is in the first or second person. In these cases, the Hungarian indefinite forms have definite equivalents in Mordvin. This is partly the result of the more complicated nature of the definite conjugation in Mordvin; or, as Trosterud (2006) puts it, the Mordvin system has more dimensions.

\section{Research background}

\subsection{Background to the research on language acquisition}

The first papers investigating the acquisition order of English morphology were published in the 1970's (Dulay \& Burt 1974; Bailey et al. 1974), and they pointed out that certain morphemes of English are acquired in a predictable order by children of various native languages. A partial overlap was also discovered with L1 acquisition order (Dulay 
et al. 1982: 211-214) which drew attention to the possible similarities between L1 and L2 acquisition. Of course, research soon began on the acquisition of other levels of linguistic structure including phonology, syntax and pragmatics. After the first steps the scope of research became more focused and methods became more sophisticated. The theoretical background constituted by psychology, psycholinguistics, and linguistics has continued to evolve, offering new perspectives.

The role that L1 plays in L2 learning is a very complex issue which has been investigated since research in second language research (SLA) began. The influence of the $\mathrm{L} 1$ has been interpreted in various ways across the wide range of SLA theories. A brief overview of the topic is given by Kaivapalu and Martin (2007) who also present their results concerning the cross-linguistic influence in morphology. Their paper is of special interest because it draws attention to the new research perspectives offered by the acquisition of Finno-Ugric languages. The present paper limits itself to examining whether certain shared typological features of the Mordvin and Hungarian languages benefit learners of Hungarian; however, the immediate goal is not to elaborate on the characteristics of a possible transfer effect. The contrastive description of the Mordvin and the Hungarian definite conjugation in section 2 reveals that although both languages distinguish between the definite and the indefinite conjugation, there are also very significant differences which probably increase the difficulty learners of Hungarian have in making use of their knowledge of the Mordvin definite conjugation. The results of the questionnaire on which this paper is based also suggest that learners of Hungarian whose native language is Mordvin do not perform any better in general than those whose mother tongue is not related to Hungarian at all.

Selinker's (1972) widely used concept of interlanguage considers the production of L2 learners not as a faulty L1 but rather as a linguistic system which approximates the target language while exhibiting features of the L1. It uses overgeneralized rules of the target language, while also inventing new rules. The concept of interlanguage is crucial 
to our present research, especially because our method for evaluating the responses to the questionnaires includes all types of answers in the analysis, not only the correct ones.

Of the few studies that have focused on the acquisition of Hungarian, only one investigates the acquisition of the grammatical structure treated in this paper. My previous results based on this questionnaire (Durst 2009; 2010; and section 3.3. below) can be compared with Langman and Bayley's (2002) research, in which the authors examined the acquisition of the Hungarian verbal morphology by Chinese learners with special attention to the acquisition of the definite / indefinite conjugation. The structure of their research reveals shortcomings of the linguistic approach to the Hungarian definite conjugation, and these may have distorted their results. A major limitation is that the study handles the Hungarian definite conjugation purely as a morphological issue and does not differentiate between real grammatical competence and grammatical structures appearing in lexically acquired units. This makes it impossible to account for complexity of the acquisition of this grammatical feature, which involves various linguistic levels including morphology, syntax and semantics. Indeed according to Pienemann's Processability Theory (1998) different processing mechanisms play a role in the process of its acquisition. In my research I differentiated between the different object complexes, which correspond to the different levels in Pienemann's model (1998). The significant differences between them in our results point to the validity of the hierarchy of the processing procedures as stated in the Processability Theory.

In my previous research based on the same questionnaire (Durst $2009 ; 2010)$ it was not possible to include the effect of the L1 in the analysis because the group of respondents was very heterogeneous, consisting of 83 people with 11 different L1s. Since each L1-L2 configuration constitutes a different system of interactions, the role of the L1 may be examined only if this heterogeneous group can be compared to another group in which all the respondents have the same L1 and where there 
are similarities in other characteristics including age and educational background. Due to the large number of other variables in our previous research, we could not take these demographic factors into account; in the present research, comparison of some demographic factors of the two groups has been possible.

Methodologically, it is important to note that the present research does not examine the process of acquisition but rather offers a crosssectional view of the language proficiency of two groups of learners. As such it sheds specific light on the characteristics of certain developmental stages in the acquisition of Hungarian as a foreign language. Most studies so far have been based on interviews or other types of oral production. However, examination of a grammatical issue as complex as the definite conjugation in Hungarian surely cannot be based on this approach alone.

\subsection{Method}

In our questionnaire, the test questions examining verb conjugation included the Hungarian present, past, imperative and infinitive forms. Sentences requiring the use of the present, the past, the imperative and the infinitive forms were separated; tasks were clearly set and very precisely explained. The grammatical subjects to each sentence were given in brackets, so the respondents only had to decide whether they should use definite or indefinite conjugation, to select the correct verb stem and the correct personal ending.

From the preparatory stage on, the possibility of examining interlanguage forms (i.e. incorrect answers) was one of the most important goals of this project. Therefore evaluation was based on a code system which made it possible to examine the responses from several points of view. Both the questions and the answers had a code and the results were recorded in an SPSS database file to be analysed later with the help of an Excel program. Here is an example from the test that demonstrates this evaluation system: 
(9) (mi) Ebéd után Pistá-t

(we) lunch after Pista-ACC

'We take Pista to the station after lunch.' (kivisz) az állomás-ra. (take) the station-ALL

On the top of the page it was clearly written that respondents should use present tense indicative. In this sentence the answer is evaluated according to the following aspects:

1) Is the choice between definite / indefinite conjugation correct?

2) Is the verb stem correct?

3) Is the answer morphologically precise?

4) Are the rules of vowel harmony correctly followed?

Using this method an answer like ${ }^{\star} k i$-visz-ünk (out-take-PL1) (in which indefinite conjugation is used instead of definite conjugation) instead of the correct ki-vis-szük (out-take-SG3<PL1) qualified as correct with resepct to questions 2), 3), 4) and it was considered incorrect only with respect to 1). Out of the 19 possible evaluation codes there was always exactly one which contained all the necessary information about the response.

\subsection{Results of previous research}

The questionnaire we used in this study had originally been used in a project intended to examine the use and acquisition of noun and verb stems, as well as the two types of conjugation. One of the main objectives in the doctoral dissertation based on the questionnaire (Durst 2010), was establishing an order of difficulty among the object complexes requiring definite conjugation; therefore special care was taken to include the different types of object complexes in similar numbers. In the test questions only the most typical cases appear; these represent the most important syntactic and semantic characteristics examined in the present research. The following object complexes appear in the test sentences: 
a) The object is a proper name.

(10) Ismer-em Pistá-t.

know-SG3<SG1 Pista-ACC

'I know Pista.'

b) The object has a definite article.
(11) Lát-om az autó-t.
see-SG3<SG1 DEF car-ACC
'I see the car.'

c) The object is the 3 SG.ACC personal pronoun öt.
(12) Ismer-em
ö- $t$.
know-SG3<sG1 (s)he-ACC
'I know him/her'

d) The object is a ("definite") pronoun carrying the suffix -ik.
(13) $A z$ egyik-et lát-om.
DEF one.of.many-ACC see-SG3<SG1
'I can see one of them.'

e) The object is an object complement clause and it is not introduced by a referential azt (that-ACC) in the main clause.
(14) Tud-om, ki vagy.
know-SG3<SG1 who be.SG2
'I know who you are.'

f) The definite object is a zero only implied by the objective conjugation of the verb.

(15) Lát-od?

see-SG3 $<$ SG1

'Can you see it/him/her?'

The test sentences also contain intransitive verbs and verbs with indefinite objects. Let us now present only those results that are pertinent to our current study. It was assumed that it is easier for language learners to 
identify the definiteness of an object if it appears explicitly and if its definiteness is semantically clear. Therefore it was assumed that respondents would make more mistakes in those cases where the definiteness of the grammatical object is more difficult to identify (e.g. the object with the $-i k$ sign or a definite zero object implied only by the definite conjugation). The chart below shows the results of Group 1, composed of 83 respondents of various L1s.

TAB LE 2. The definite / indefinite conjugation according to the object complexes

\begin{tabular}{|c|c|c|}
\hline Object type & $\begin{array}{l}\text { Correct } \\
\text { answers }\end{array}$ & $\begin{array}{l}\text { The choice between } \\
\text { the definite / indefinite } \\
\text { conjugation is correct but } \\
\text { there are other mistakes } \\
\text { (interlanguage form) }\end{array}$ \\
\hline a) The object is a proper name & $77.17 \%$ & $85.97 \%$ \\
\hline b) The object has a definite article & $62.33 \%$ & $82.52 \%$ \\
\hline $\begin{array}{l}\text { c) The object is the pronoun öt } \\
\text { 'him/her' }\end{array}$ & $57.07 \%$ & $76.93 \%$ \\
\hline $\begin{array}{l}\text { d) The object is a pronoun with } \\
\text { the suffix - } i k\end{array}$ & $50.61 \%$ & $59.76 \%$ \\
\hline $\begin{array}{l}\text { e) The object is a clause which is } \\
\text { not introduced by a referential } \\
\text { azt in the main clause }\end{array}$ & $57.81 \%$ & $70.08 \%$ \\
\hline $\begin{array}{l}\text { f) The object is a zero } \\
\text { representing a definite object }\end{array}$ & $57.65 \%$ & $66.21 \%$ \\
\hline $\begin{array}{l}\text { g) The verb is intransitive or it has } \\
\text { an indefinite object }\end{array}$ & $76.38 \%$ & $94.3 \%$ \\
\hline
\end{tabular}

Looking only at the correct answers, we can see that groups g) and a) have the highest proportion of correct answers where intransitive verbs or indefinite objects and proper nouns are used as objects. There are significant differences between the different types of objects. In groups a) 
and b) proper names and objects with a definite article are in the first place, which can be explained by their explicit presence and the semantic clearness of their definiteness. In general, we can say that groups d), e) and $\mathrm{f}$ ) have the worst results and that the proportion of correct answers is remarkably low in group d) (objects with the $-i k$ sign).

The lower number of correct answers in groups e) and f) seems to prove the assumption and can be explained by the fact that the grammatical object is not explicitly present. The poor results in d) may be explained by its grammatical complexity: the -ik suffix rarely appears on the object itself (egyik-et 'one.of.them-ACC', valamelyik-et 'any.of.themACC'), rather it appears on the pronoun preceding the object (az egyik almá-t 'DEF one.of.them apple-ACC', valamelyik almá-t 'any.of.them apple-ACC').

In light of Hungarian L1 acquisition data (Meggyes 1971; Lengyel 1981; Weber 2007; 2008) it may be deduced that the L1 and L2 acquisition of the Hungarian definite conjugation follow a very different pattern. In the acquisition process of Hungarian children learning their native language the definiteness of the objects appears first on a conceptual level in "here and now" situations while foreign learners (especially in instructed learning settings) can identify the definiteness of only those objects that are very clearly definite and that appear explicitly to begin with.

\section{Subjects}

As shown by table 3, which summarizes the most important data about the respondents, the two groups have a high degree of similarity in several aspects. The average age and the time spent learning Hungarian is almost identical in the two groups, which is fundamental for comparison purposes. There were various (11) L1s in Group 1 but none of them distinguished definite and indefinite verb conjugation; this feature is shared only by the target language and Erzya-Mordvin. Also it is important to note that practically all speakers of Erzya- 
Mordvin are bilingual and speak Russian fluently. Therefore the test environment in this case was also bilingual, thus decidedly different from the target language environment of Group 1. The number of languages spoken (including L1) is similar in the two groups, although it is somewhat lower in Group 2. It might also be important to note that out of the average of 2.9, Russian accounts for 1 in each case. The greatest difference between the two groups is the number of respondents and the time spent in the target language environment. The difference in group size warns us to be very cautious when drawing conclusions; however, the difference between the time spent in a target language environment leads us to expect differences in the results of the two groups. Besides the fact that people in Group 2 had spent considerably less time in Hungary it is also significant that there were only 3 people in this group who had spent any time in the target language environment. The fact that Group 2 filled in only one part of the questionnaire (the one examining the use of verbs) may have positively influenced the respondents' ability to concentrate on the task, and may therefore have contributed to better results in general.

TABLE 3. The respondents in Group 1 and Group 2

\begin{tabular}{|l|c|c|}
\hline & Group 1 & Group 2 \\
\hline Age (average) & 23.19 years & 22.6 years \\
\hline L1 & 11 & Erzya-Mordvin - Russian \\
\hline Test environment & target language & L1 - Russian \\
\hline $\begin{array}{l}\text { Duration of learning } \\
\text { Hungarian (average) }\end{array}$ & 4 years & 3.8 years \\
\hline $\begin{array}{l}\text { Time spent in Hungary } \\
\text { (average) }\end{array}$ & 1.16 years & 0.09 years (only 3 people) \\
\hline Languages (average) & 3.3 & 2.9 (including Russian!) \\
\hline Number & 83 & 11 \\
\hline
\end{tabular}




\section{Results}

The data in table 4 clearly shows that the results of Group 2 (the ErzyaMordvin group) are generally worse than in Group 1, which may be attributed to a generally lower language proficiency. The proportion of correct answers in Group 2 is $4.73 \%$ to $29.24 \%$ lower in each case. However, such a difference in general language proficiency does not explain the particularly large differences in c), e) and f) (these lines are highlighted). The object complex that appears in c) is the 3SG.ACC personal pronoun $o t$ and in this case the difference between the results of Group 1 and Group 2 is 17,45\%; in e) the object is an object clause and it is not introduced by a referential azt in the main clause. Here the difference between the two groups is $29,24 \%$ while in $\mathrm{f}$ ) the definite object is a zero only implied by the definite conjugation; it does not appear explicitly and in this case the difference between the results of Group 1 and Group 2 is $22,65 \%$. The Erzya-Mordvin respondents gave considerably fewer correct answers where the object in the sentence was the third person personal pronoun (c) and when the object did not explicitly appear in the sentence (e and $\mathrm{f}$ ).

It is of course impossible to clearly identify the reason behind the incorrect answers but in these cases we may assume that the two factors described above played an important role. Contrastive analysis revealed that the definiteness of a third person personal pronoun as the grammatical object is a problematic issue, since different rules apply in the two languages, which may lead to uncertainties when deciding on the conjugation. The other important factor seems to be the explicitness of the object. Our new data seems to prove again that it is more difficult for learners of Hungarian to identify objects that are not present in the sentence explicitly; the typological similarities between the Hungarian and the Erzya-Mordvin languages do not seem to influence this. The significant difference between the results of Group 1 and Group 2 may suggest that the time spent in the target language environment helps learners develop the competence to identify implicit definite objects. Textbooks 
rarely present situations where this object complex appears, while it is very common in real life situations that a definite object is implied by the context or simply by pointing at something.

TABLE 4. Correct choices between the definite / indefinite conjugation according to the object complexes in the two groups

\begin{tabular}{|c|c|c|c|c|}
\hline \multirow[t]{2}{*}{ Object type } & \multicolumn{2}{|c|}{ Correct answers } & \multicolumn{2}{|c|}{$\begin{array}{l}\text { The choice between } \\
\text { the definite / indefi- } \\
\text { nite conjugation is } \\
\text { correct but there are } \\
\text { other mistakes (inter- } \\
\text { language form) }\end{array}$} \\
\hline & G1 & G2 & G1 & G2 \\
\hline $\begin{array}{l}\text { a) The object is a proper } \\
\text { name }\end{array}$ & $77.17 \%$ & $69.44 \%$ & $85.97 \%$ & $82.41 \%$ \\
\hline $\begin{array}{l}\text { b) The object has a definite } \\
\text { article }\end{array}$ & $62.33 \%$ & $57.6 \%$ & $82.52 \%$ & $83.74 \%$ \\
\hline $\begin{array}{l}\text { c) The object is the pronoun } \\
\text { "ot 'him/her' }\end{array}$ & $57.07 \%$ & $39.62 \%$ & $76.93 \%$ & $64.15 \%$ \\
\hline $\begin{array}{l}\text { d) The object is a pronoun } \\
\text { with the suffix - } i k\end{array}$ & $50.61 \%$ & $40.4 \%$ & $59.76 \%$ & $46.46 \%$ \\
\hline $\begin{array}{l}\text { e) The object is a clause } \\
\text { which is not introduced } \\
\text { by a referential azt in the } \\
\text { main clause }\end{array}$ & $57.81 \%$ & $28.57 \%$ & $70.08 \%$ & $35.29 \%$ \\
\hline $\begin{array}{l}\text { f) The object is a zero } \\
\text { representing a definite } \\
\text { object }\end{array}$ & $57.65 \%$ & $35 \%$ & $66.21 \%$ & $43 \%$ \\
\hline $\begin{array}{l}\text { g) The verb is intransitive or } \\
\text { it has an indefinite object }\end{array}$ & $76.38 \%$ & $70.26 \%$ & $94.3 \%$ & $91.57 \%$ \\
\hline
\end{tabular}




\section{Conclusion}

We may conclude that the typological similarities between the Hungarian and the Erzya-Mordvin languages probably do not facilitate the acquisition of the Hungarian definite conjugation. Our results suggest that time spent in the target language environment helps learners acquire the use of the definite conjugation, especially in cases where an implicit object is implied by the context, that is, on higher levels of processing procedures (Pienemann 1998). The low number of respondents warns us that these are not firm conclusions but they may be used as the basis for further investigation.

\section{Abbreviations}

$\begin{array}{ll}1 & \text { 1st person } \\ 3 & \text { 3rd person } \\ \text { ABL } & \text { ablative } \\ \text { ACC } & \text { accusative } \\ \text { ALL } & \text { allative } \\ \text { DEF } & \text { definite } \\ \text { GEN } & \text { genitive } \\ \text { PAST } & \text { past tense } \\ \text { PL } & \text { plural } \\ \text { POSS } & \text { possessive } \\ \text { SG } & \text { singular }\end{array}$

\section{References}

Alhoniemi, Alho 1996. Über die Unterschiede bei der Verwendung der Subjektund Objektkonjugation im Ersa- und Moksha-Mordwinischen. - Heikki Leskinen, Sándor Maticsák, Paavo Pulkkinen, Risto Raittila, Tõnu Seilenthal (Hrsg.). Congressus Octavus Internationalis Fenno-Ugristarum VIII/3. Jyväskylä, 68-71.

Bailey, Nathalie, Carolyn Madden, Stephen Krashen 1974. Is there a "natural sequence" in adult second language learning? - Language Learning 24, 235-243. doi:10.1111/j.1467-1770.1974.tb00505.X 
Balásné, Szalai Edit 1999. A határozottság kifejezése a magyar és a mordvin nyelvben. - V. Raisz Rózsa, H. Varga Gyula (Szerk.). Nyelvi és kommunikációs kultúra az iskolában I. A Magyar Nyelvtudományi Társaság kiadványai 212. Budapest: Magyar Nyelvtudományi Társaság, 381-387.

Dulay, Heidi, Marina Burt 1974. Natural sequences in child second language acquisition. - Language Learning 24, 37-53. doi:10.1111/j.1467-1770.1974. tb00234.x

Dulay, Heidi, Marina Burt, Stephen Krashen 1982. Language Two. Rowley, Mass.: Newbury House.

Durst, Péter 2009. A magyar igeragozás elsajátításának vizsgálata magyarul tanuló külföldieknél - különös tekintettel a határozott és határozatlan ragozásra. - Hungarológia Évkönyv 10, 11-20.

Durst, Péter 2010. A magyar mint idegen nyelv elsajátításának vizsgálata - különös tekintettel a fónévi és igei szótövekre, valamint a határozott tárgyas ragozásra. Unpublished $\mathrm{PhD}$ thesis. University of Pécs.

Fisiak, Jacek (Ed.) 1981. Theoretical Issues in Contrastive Linguistics. Current Issues in Linguistic Theory 12. Amsterdam: John Benjamins.

Havas, Ferenc 2005. Tárgyas ragozás és medializáció. - Budapesti Uráli Műhely IV. Uráli Grammatizáló. Budapest: MTA Nyelvtudományi Intézet, 147-186.

Keresztes, László 1999. Development of Mordvin Definite Conjugation. Mémoires de la Société Finno-Ougrienne 233. Helsinki: Finno-Ugrian Society.

Kaivapalu, Annekatrin, Maisa Martin 2007. Morphology in transition: The plural inflection of Finnish nouns by Estonian and Russian learners. - Acta Linguistica Hungarica 54 (2), 129-156. doi:10.1556/ALing.54.2007.2.2

Lengyel, Zsolt 1981. Tanulmányok a nyelvelsajátítás köréből. Nyelvtudományi értekezések 107. Budapest: Akadémiai Kiadó.

Langman, Juliet, Robert Bayley 2002. The acquisition of verbal morphology by Chinese learners of Hungarian. - Language Variation and Change 14, 55-77. doi:10.1017/S0954394502141032

Meggyes, Klára 1971. Egy kétéves gyermek nyelvi rendszere. Nyelvtudományi Értekezések 73. Budapest: Akadémiai Kiadó.

Mészáros, Edit 2000. Az erza-mordvin nyelv alapjai. Budapesti Finnugor Füzetek 14. Budapest: Eötvös Loránd Tudományegyetem, Finnugor Tanszék.

Patayné Salamon, Ágnes 1983. Az erza-mordvin tárgyas szerkezetek. Unpublished $\mathrm{PhD}$ thesis. University of Debrecen.

Pienemann, Manfred 1998. Language Processing and Second Language Development: Processability Theory. Amsterdam, Philadelphia: John Benjamins. 
Raun, Alo 1988. The Mordvin language. - Denis Sinor (Ed.). The Uralic languages: Description, History and Foreign Influences. Handbuch der Orientalistik 8. Leiden: Brill, 96-110.

Selinker, Larry 1972. Interlanguage. - IRAL 10, 209-230. doi:10.1515/ iral.1972.10.1-4.209

Trosterud, Trond 2006. Homonymy in the Uralic Two-Argument Agreement Paradigms. Mémoires de la Société Finno-Ougrienne 251. Helsinki: Finno-Ugrian Society.

Weber, Katalin 2007. Elemi tárgyas predikátumok jelentésszerkezetének kiépülése a magyarban (L1, L2). - Tamás Váradi (Szerk.). I. Alknyelvdok: Konferencia kötet. Budapest: MTA Nyelvtudományi Intézet. http://www.nytud. hu/alknyelvdok07/proceedings07/Weber.pdf (18.2.2011).

Weber, Katalin 2008. A magyar nyelvelsajátítás mint ősszöveg. - Szilárd Tátrai, Gábor Tolcsvai Nagy (Szerk.). Szöveg, szövegtípus, nyelvtan. Budapest: Tinta.

Zaicz, Gábor 2003. A mordvin tárgyas szerkezetekről. - Beatrix Oszkó, Mária Sipos (Szerk.). Uráli TÁRGYaló. 2002. január 10-12. Budapest: MTA Nyelvtudományi Intézet, 164-177.

Zaicz, Gábor 2004. The Mordvin language. - György Nanovfszky (Ed.). The Finno-Ugric world. Budapest: Teleki László Foundation, 209-215.

\section{Péter Durst}

University of Szeged, Hungarian Studies Center

Tisza Lajos krt. 103

H-6725 Szeged, Hungary

University of Zagreb, Department of Hungarology

Ivana Lučića 3

10000 Zagreb, Croatia

durst.peter@gmail.com

\section{Boglárka Janurik}

University of Szeged, Department of Finno-Ugric Studies

Tisza Lajos krt. 103

H-6725 Szeged, Hungary

janurikbogi@yahoo.com 


\title{
Erinevate emakeeltega õppijate ungari keele määratud konjugatsiooni omandamine
}

\author{
PÉTER DURST \\ Szegedi Ülikool, Zagrebi Ülikool \\ BOGLÁRKA JANURIK \\ Szegedi Ülikool
}

Ungari keeles esineb palju erinevaid grammatilisi ühildumistüüpe. Üks neist on maailma keeltes eriti haruldane ja tekitab raskusi ungari keele õppijatele. Ungari keeles markeeritakse määratud objekt ka verbivormis. Sõltuvalt objekti definiitsusest tehakse niisiis vahet määratud ja märamata paradigmade vahel kõigis pöördtüüpides käskiva ja tingiva kõneviisi olevikus ja minevikus.

Artikkel käsitleb ungari keele määratud ja määramata konjugatsioonide omandamist kahes õppijarühmas. Esimene grupp koosneb erinevate emakeeltega õppijatest, teises rühmas on informantide emakeeleks ersa keel. Kuna objekti definiitsus on markeeritud verbis nii ungari kui ersa keeles, uurisime, kas see ühine tunnusjoon aitab ersalasi ungari keele objekti pööramise omandamisel.

Kuna analüüsi tegemiseks on vajalik ülevaade nii ungari kui ersa keele konjugatsioonsüsteemist, eelneb uurimistöö andmete esitusele võrdlev kokkuvõte mõlema keele määratud konjugatsioonist.

Uurimus põhineb küsimustikul, mis koosneb 446-st testiküsimusest. Küsimustikul on kaks põhiosa, mis sisaldavad vastavalt 236 ning 210 testiküsimust. Tegusõna pööramist uuriti teises osas, kus õppijatel paluti kirjutada sulgudes oleva verbi õige vorm. Erinevate emakeeltega õppijarühm täitis küsimustiku mõlemad osad, ersakeelsed õppijad täitsid vaid konjugatsiooni sisaldava teise osa.

Uurimuse tulemusena selgus, et tüpoloogilised sarnasused ungari ja ersa keele vahel ei hõlbusta ungari keele määratud konjugatsiooni omandamist. Tulemused näitavad, et sihtkeele keskkonnas veedetud aeg aitab õpilastel omandada määratud konjugatsiooni kasutuse reeglid, eriti implitsiitse objekti puhul.

Võtmesõnad: teise keele omandamine; esimese keele mõju; ühildumine; määratud objekt; sihtkeele keskkond; ersa keel; ungari keel 